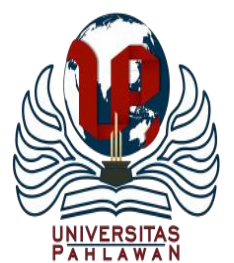

Edukatif : Jurnal Ilmu Pendidikan Volume 3 Nomor 6 Tahun 2021 Halm 3675 - 3688 EDUKATIF: JURNAL ILMU PENDIDIKAN

Research \& Learning in Education

https://edukatif.org/index.php/edukatif/index

\title{
Pengaruh Pendidikan Karakter terhadap Kedisiplinan Peserta Didik di Sekolah Dasar
}

\author{
Ferdinandus Etuasius Dole ${ }^{凶}$ \\ Universitas Flores, Indonesia \\ E-mail : doleferdinand@gmail.com
}

\begin{abstract}
Abstrak
Masalah yang diangkat pada penelitian ini adalah: 1) Bagaimana pendidikan karakter peserta didik Gugus 01 Detukeli? 2) Bagaimana tingkat kedisiplinan peserta didik Gugus 01 Detukeli? dan 3) Bagaimana pengaruh pendidikan karakter terhadap kedisiplinan peserta didik kelas Gugus 01 Detukeli? tujuan Penelitian ini Untuk mengetahui: 1) sejauhmana Penerapan pendidikan karakter peserta didik kelas Gugus 01 Detukeli; 2) tingkat kedisiplinan peserta didik Gugus 01 Detukeli; dan, 3) adanya pengaruh pendidikan karakter terhadap kedisiplinan peserta didik Gugus 01 Detukeli. Penelitian ini menggunakan penelitian kuantitatif korelasional, yang dilaksanakan di Sekolah dasar dalam Gugus 01 Kecmatan Detukeli, yang terdiri dari SDK Magekoba, SDI Aedari, SDN Kurupoke dan SDK Gaibhabha, dengan Jumlah Guru sebanyak 30 orang yang keseluruhannya menjadi subyek penelitian ini. Data dikumpulkan melalui angket. Pengujian hipotesis menggunakan analisis Regresi Linear Sederhana dengan rumus Korelasi Product Moment Pearson. Adapun hasil dari penelitian ini menunjukkan bahwa 1) rata-rata Pendidikan Karakter sebesar 114, sesuai dengan interval nilai variabel X Pendidikan Karakter, maka disimpulkan bahwa pendidikan karakter di gugus 01 Detukeli berada pada kategori cenderung Sedang. 2) rata-rata variabel kedisplinan 11, interval nilai variabel Y Pendidikan Karakter, maka dapat disimpulkan bahwa kedisplinan di gugus 01 Detukeli berada pada kategori cenderung Sedang. 3) pengaruh pendidikan karakter terhadap kedisiplinan peserta didik Gugus 01 Detukeli ditunjuk oleh koofesien korelasi $(\mathrm{R})=0,730$ yang menyatakan bahwa indeks korelasi (r) X terhadap $\mathrm{Y}\left(\mathrm{R}^{2}\right) 0,532$. Nilai $\mathrm{F}$ berada pada signifikan $0,000<0,05$, sehingga hipotesis diterima dan disimpulkan bahwa pendidikan karakter berpengaruh secara signifikan terhadap kedisiplinan peserta didik.
\end{abstract}

Kata Kunci: Pedidikan Krakter, kedisiplinan

\begin{abstract}
The problems raised in this study are: 1) How is the character education of the students of Region 01 Detukeli? 2) How is the discipline level of the students of Region 01 Detukeli? and 3) How is the influence of character education on the discipline of students in the Region 01 Detukeli class? The purpose of this study is to find out: 1) the extent to which the application of character education for students in the class of Region 01 Detukeli; 2) the level of discipline of students in Region 01 Detukeli; and, 3) the influence of character education on the discipline of students in Region 01 Detukeli. This study uses correlational quantitative research, which was carried out in elementary schools in Region 01 of the Detukeli District, consisting of SDK Magekoba, SDI Aedari, SDN Kurupoke and SDK Gaibhabha, with a total of 30 teachers who were the subjects of this study. Data was collected through a questionnaire. Hypothesis testing using Simple Linear Regression analysis with the Pearson Product Moment Correlation formula. The results of this study indicate that 1) the average character education is 114, according to the interval value of the variable X Character Education, it can be concluded that character education in the 01 Detukeli area is in the category of moderately inclined 2) the average of the discipline variable is 11, the interval value of the $Y$ variable is Character Education, it can be concluded that the discipline in the 01 Detukeli area is in the moderately inclined category. 3) the effect of character education on student discipline in Region 01 Detukeli is indicated by the correlation coefficient $(R)=0.730$ which states that the correlation index $(r) X$ to $Y(R 2)$ is 0.532 . The $F$ value is significant at $0.000<0.05$, so the hypothesis is accepted and it is concluded that character education has a significant effect on student discipline.
\end{abstract}

Keywords: Character Education, discipline

Copyright (c) 2021 Ferdinandus Etuasius Dole

$\triangle$ Corresponding author:

Email : doleferdinand@gmail.com

DOI $\quad:$ https://doi.org/10.31004/edukatif.v3i6.1026 
3676 Pengaruh Pendidikan Karakter terhadap Kedisiplinan Peserta Didik di Sekolah Dasar - Ferdinandus Etuasius Dole

DOI: https://doi.org/10.31004/edukatif.v3i6.1026

\section{PENDAHULUAN}

Salah satu nilai karakter yang perlu dikembangkan adalah disiplin. Nilai karakter disiplin sangat penting dimiliki oleh manusia agar kemudian muncul nilai-nilai karakter yang baik lainnya. Pentingnya penguatan nilai karakter disiplin didasarkan pada alasan bahwa sekarang banyak terjadi perilaku menyimpang yang bertentangan dengan norma kedisiplinan. Perilaku tidak disiplin juga sering ditemui di lingkungan sekolah, termasuk sekolah dasar. Sebagai contoh perilaku tidak disiplin tersebut antara lain datang ke sekolah tidak tepat waktu tidak memakai seragam sesuai tata tertib sekolah, duduk atau berjalan dengan seenaknya menginjak tanaman, membuang sampah sembarangan, mencoret-coret dinding sekolah, membolos sekolah, mengumpulkan tugas tidak tepat pada waktunya, dan sebagainya. Terjadinya perilaku tidak disiplin di sekolah menunjukkan bahwa telah terjadi permasalahan dalam hal pendidikan karakter disiplin. Munculnya perilaku tidak disiplin menunjukkan bahwa pengetahuan yang terkait dengan karakter yang didapatkan siswa di sekolah belum membawa dampak positif terhadap perubahan perilaku siswa sehari-hari. Pada dasarnya siswa tahu bahwa perilakunya tidak benar tetapi mereka tidak memiliki kemampuan untuk membiasakan diri menghindari perilaku yang salah tersebut. Hal ini merupakan dalam proses pendidikan karakter yang terjadi. Proses pembelajaran lebih banyak mengajarkan siswa pengetahuan verbalistik yang kurang mempersiapkan siswa agar mampu menghadapi kehidupan sosial yang akan mereka temui.

Untuk dapat membentuk karakter yang baik dalam diri peserta didik, maka sekolah hendaknya mengembangkan tiga aspek penting,yaitu moral knowing (pengetahuan moral), moral feeling (perasaan moral) dan moral action (perilaku moral) (Lickona, 1991). Menurut pendapat (Lickona, 1991) menjelaskan bahwa sekolah merupakan suatu lembaga pendidikan yang mengemban tugas mengembangkan nilai karakter. Nilainilai karakter itu antaralain kejujuran, keterbukaan, toleransi, saling menolong dan kasih sayang, keberanian dan dan nilai-nilai demokrasi. Dari sejumlah nilai karakter yang perlu ditanamkan tersebut, disiplin diri merupakan salah satu nilai karakter yang penting dikembangkan. Curvin dan Mindler (1992: 12) mengemukakan bahwa ada tiga dimensi disiplin, yaitu (1) disiplin untuk mencegah masalah; (2) disiplin untuk memecahkan masalah agar tidak semakin buruk; dan (3) disipilin untuk mengatasi siswa yang berlaku di luar kontrol.

Permasalahan yang diangkat adalah: 1). Bagaimana pendidikan karakter peserta didik SD Gugus 01 Kecamatan Detukeli? 2). Bagaimana tingkat kedisiplinan peserta didik SD Gugus 01 Kecamatan Detukeli? 3). Bagaimana pengaruh pendidikan karakter terhadap kedisiplinan peserta didik SD Gugus 01 Kecamatan Detukeli? Adapun tujuannya penelitian ini: 1). Untuk mengetahui sejauhmana Penerapan pendidikan karakter peserta didik SD Gugus 01 Kecamatan Detukeli; 2) Untuk mengetahui tingkat kedisiplinan peserta didik SD Gugus 01 Kecamatan Detukeli; 3). Untuk mengetahui adanya pengaruh pendidikan karakter terhadap kedisiplinan peserta didik SD Gugus 01 Kecamatan Detukeli.

Menurut Pusat Bahasa Depdiknas karakter adalah bawaan, hati, jiwa, kepribadian, budi pekerti,perilaku,personalitas,sifat, tabiat,watak. Karakter berasal dari kata Yunani yang berarti to mark atau menandai dan memfokuskan bagaimana mengaplikasikan nilai kebaikan dalam bentuk tindakan atau tingkah laku sehingga orang yang tidak jujur, kejam, rakus dan perilaku jelek lainnya dikatakan orang berkarakter jelek. Sebaliknya, orang yang perilakunya sesuai dengan kaidah moral disebut dengan karakter mulia (Amri et al., 2011)

Dari defenisi karakter di atas, maka dapat disimpulkan bahwa karakter adalah suatu kebiasaan yang didalamnya termasuk cara berpikir dan berperilaku yang mengarahkan tindakan seseorang dalam bersikap dikondisi-kondisi tertentu. Karakter seorang menentukan bagaimana individu bertindak pada saat individu tersebut berpikir bahwa dirinya tidak terlihat oleh lain. Atau seperti pepatah lama yang berbunyi,"karakter adalah apa yang Anda lakukan ketika tidak ada orang yang melihat”. (Lickona, 2012). Tanpa sadar, karakter kita akan terlihat pada saat orang lain tidak melihat. Karena pada saat itu, kita tidak akan menyembunyikan 
3677 Pengaruh Pendidikan Karakter terhadap Kedisiplinan Peserta Didik di Sekolah Dasar - Ferdinandus Etuasius Dole

DOI: https://doi.org/10.31004/edukatif.v3i6.1026

siapa dan bagaimana diri kita. Dengan kata lain, seseorang akan menjadi dirinya sendiri saat tidak ada orang yang melihat.

Menurut Suyanto (Agung 2011: 394) character is a way of thinking and behavior of each individual to live and cooperate in the environment of family, society, nation, and country. An individual with a good character is the individual who can make a decision and ready to take responsibility of decision results. Karakter adalah cara berpikir dan berperilaku dari masing-masing individu untuk hidup dan bekerjasama dalam lingkungan keluarga, masyarakat, bangsa dan negara. Seorang individu dengan karakter yang baik adalah individu yang bisa membuat keputusan dan siap mengambil tanggungjawab atas hasil keputusan.

Dari beberapa pendapat para ahli di atas peneliti dapat menyimpulkan bahwa karakter merupakan perilaku yang ditimbulkan oleh masing-masing individu untuk berinteraksi dengan lingkungan sekitarnya dan mampu menerapkan pola perilaku yang baik serta memiliki rasa empatik dan bertanggung jawab mengembangkan kemampuan untuk memberikan keputusan baik-buruk dan mewujudkan kebaikan dalam kehidupan sehari- hari dengan sepenuh hati.

Menurut (Rohman et al., 2012) mengatakan pendidikan karakter adalah suatu sistem penanaman nilainilai karakter yang meliputi komponen pengetahuan pengetahuan, kesadaran atau kemauan dan tindakan untuk melaksanakan nilai - nilai tersebut. Pendidikan karakter dapat dimaknai sebagai"The deliberate use of all dimensions of school life to foster optimal character development". Dalam pendidikan karakter di sekolah, semua komponen harus dilibatkan, termasuk komponen-komponen pendidikan itu sendiri yaitu isi kurikulum, proses pembelajaran dan penilaian,penanganan atau pengelolaan mata pelajaran, pengelolaan sekolah, pelaksanaan aktivitas, pemberdayaan sarana prasarana, pembiayaan, dan etos kerja seluruh warga sekolah / lingkungan (Indaayu, 2017:345).

Dr. Marvin Berkowizt (Megawangi, 2010) menagatkan bahwa pendidikan karakter merupakan pendidikan budi pekerti plus, yaitu yang melibatkan aspek pengetahuan (cognitive), perasaan (feeling) dan tindakan (action). Menurut (Lickona, 2012), tanpa ketiga aspek ini maka pendidikan karakter tidak akan efektif dan pelaksanaannya pun harus dilaksanakan pun harus dilakukan secara sistematis dan berkelanjutan. Dengan pendidikan karakter seorang anak akan menjadi cerdas emosinya. Seseorang dapat dikatakan berkarakter dan berwatak jika telas berhasil menyerap nilai dan keyakinan yang dikehendaki masyarakat serta digunakan sebagai kekutan moral dalam hidupnya.

Berdasarkan penelitian di Harvard University Amerika Serikat Alli Akbar 2000 (Amri Sofan, 2011) ternyata kesuksesan seorang tidak ditentukan semata - mata oleh faktor pengetahuan dan kemampuan teknis (hardskill) belaka, tetapi lebih oleh faktor kemampuan mengolah diri dan oranglain (softskill). Penelitian ini mengungkapkan kesuksesan adalah karena $20 \%$ hard skill dan $80 \%$ soft skill bahkan orang - orang tersukses didunia karena lebih banyak didukung oleh kemampuan soft skill daripada hard skill mereka.

Beberapa pendapat para ahli di atas peneliti dapat menyimpulkan bahwa pendidikan karakter merupakan pendidikan moral yang ditanamkan dalam diri peserta didik (sekolah dasar) berupa nilai - nilai yang tidak terlepas dari keseharian dalam proses pembelajaran. Seperti yang dikemukakan Suyanto (Ratna,2014) mengatakan bahwa dengan pendidikan karakter yang diterapkan secara sistematis dan berkelanjutan, seorang anak akan menjadi cerdas emosinya.

Pendidikan karakter (Kemendiknas, 2011) sebagai manifestasi Pancasila UUD 1945 memiliki karakter sebagai berikut: a) Pendidikan karakter bersumber dari hati yang mencerminkan beriman dan bertakwa kepada Tuhan Yang Maha Esa, bersyukur, jujur, adil amanah, sabar, disiplin dan taat aturan, berjiwa Patriotik, bertanggung jawab, pantang menyerah, dan cinta tanah air; 2) Pendidikan karater bersumber dari olah pikir yang mencerminkan kecerdasan, kritis, inovatis,analitis, produktif, menguasai IPTEKdan replektif; 3) Pendidikan karakter bersumber kinestetika yaitu sehat jasmani dan rohani, sportif, tangguh, handal, berdaya tahan, kooperatif, ulet dan gigih.; dan 4) Pendidikan karakter bersumber pada rasa, karsa, dan cipta yaitu 
3678 Pengaruh Pendidikan Karakter terhadap Kedisiplinan Peserta Didik di Sekolah Dasar - Ferdinandus Etuasius Dole

DOI: https://doi.org/10.31004/edukatif.v3i6.1026

mengedepankan aspek kemanusiaan, saling mengasihi,saling menghargai, memiliki semangat kebersamaan, ramah, peduli, hormat, kerja keras dan beretos kerja tinggi.

Dari beberapa uraian di atas, peneliti dapat menyimpulkan bahwa karakteristik pendidikan karakter dapat membentuk nilai- nilai moral yang timbul dari dalam diri dimana nilai- nilai tersebut menggambarkan perilaku atau karakter pribadi yang khas dan menerapkan nilai - nilai (religius, disiplin dan tanggung jawab) yang diyakini baik dan benar dalam rangka membentuk dan mengembangkan potensi dirinya.

Pendidikan karakter bertujuan untuk meningkatkan mutu proses dan hasil pendidikan yang mengarah pada pembentukan karakter dan akhlak mulia peserta didik secara utuh, terpadu dan seimbang, sesuai dengan standar kompetensi kelulusan pada setiap satuan pendidikan. Melalui pendidikan karakter peserta didik diharapkan mampu secara mandiri meningkatkan dan menggunakan pengetahuannya pengetahuannya, mengkaji dan menginternalisasikan nilai-nilai karakter dan akhlak mulia sehingga terwujud dalam perilaku sehari - hari.

Menurut Said Hamid Hasan (Widyahening, 2016) mengemukakan pendidikan karakter memiliki liam tujuan diantaranya: 1) Mengembangkan Potensi kalbu/ nurani / afektif peserta didik sebagai manusia dan warga negara yang memiliki nilai - nilai karakter bangsa. 2) Kebiasaan dan perilaku peserta didik yang terpuji dan sejalan dengan nilai - nilai universal dan tradisi budaya bangsa yang religius. 3) Menanamkan jiwa kepemimpinan dan tanggung jawab peserta didik sebagai generasi penerus bangsa. 4) Mengembangkan kemampuan peserta didik menjadi manusia yang mandiri, kreatif dan berwawasan kebangsaan. 5) Mengembangkan lingkungan kehidupan sekolah sebagai lingkungan belajar yang aman, jujur, penuh kreativitas dan persahabatan serta dengan rasa kebangsaan yang tinggi dan penuh kekuatan.

Menurut Zubaedi (2012) pendidikan karakter memiliki tiga fungsi utama di antaranya: Pertama, Fungsi Pembentukan Dan Pengembangan Potensi. Pendidikan karakter berfungsi membentuk mengembangkan potensi peserta didik agar berpikiran baik, berbaik hati, dan berperilaku baik sesuai dengan falsafah hidup pancasila. Kedua, Fungsi Perbaikan dan Penguatan Pendidikan Karakter berfungsi memperbaiki dan memperkuat peran keluarga, satuan pendidikan, masyarakat dan pemerintah untuk ikut berpartisipasi dan bertanggung jawab dalam pengembangan potensi warga negara dan pembangunan bangsa yang maju, mandiri dan sejahtera. Ketiga, Fungsi Penyaring. Pendidikan karakter berfungsi memilah budaya bangsa sendiri dan menyaring budaya bangsa lain yang tidak sesuai dengan nilai - nilai budaya dan karakter bangsa yang bermartabat. Ketiga fungsi ini dilakukan melalui: (1) Pengukuhan Pancasila falsafah dan ideologi negara; (2) Pengukuhan nilai dan norma konstitusional UUD 1945; (3) Penguatan komitmen kebangsaan Negara Kesatuan Republik Indonesia (NKRI) ; (4) Penguatan nilai-nilai keberagaman sesuai dengan konsepsi Bhineka Tunggal Ika; (5) Penguatan keunggulan dan daya saing bangsa untuk keberlanjutan kehidupan bermasyarakat,berbangsa dan bernegara Indonesia dalam konteks global

Menurut (Wiyani Novan Ardy, 2012) mengatakan bahwa pendidikan karakter tanpa identifikasi pilarpilar karakter, hanya akan menjadi sebuah perjalanan tanpa akhir, petualangan tanpa peta. Organisasi manapun yang berpengaruh di dunia ini, yang mempunyai perhatian besar pada pendidikan karakter seharusnya mampu mengidentifikasi karakter-karakter dasar yang menjadi pilar perilaku individu. Heritage Foundation merumuskan sembilan karakter dasar yang menjadi tujuan pendidikan karakter tersebut antara lain: a) Cinta kepada Allah dan semesta beserta isinya; b Tanggung jawab, disiplin, dan Mandiri; c) Jujur; d) Hormat dan Santun; e) Kasih sayang, peduli dan kerja sama; f) Percaya diri, kreatif, kerja keras dan pantang menyerah; g) Keadilan dan kepemimpinan; h) Baik dan rendah hati; dan i) Toleransi, cinta damai, dan persatuan.

Kemudian, menurut (Counts, 2004) enam pilar karakter berdasarkan the six pillars of character yang dikeluarkan oleh Character Counts Cualition (a project of the joseph Institute of Ethics) sebagai berikut: a) Trustworthiness, bentuk karakter yang membuat seseorang menjadi berintegritas, jujur dan loyal; b) Fairneiss, bentuk karakter yang membuat seseorang memiliki pemikiran terbuka serta tidak suka memanfaatkan orang 
lain; c) Caring, bentuk karakter yang membuat seseorang memiliki sikap peduli dan perhatian terhadap oranglain maupun kondisi sosial lingkungan sekitar; d) Respect, bentuk karakter yang membuat seseorang selalu menghargai dan menghormati oranglain; e) Citizenship, bentuk karakter yang membuat seseorang sadar hukum dan peraturan serta peduli terhadap lingkungan alam; dan f) Responsibility, bentuk karakter yang membuat seseorang bertanggungjawab, disiplin, dan selalu melakukan sesuatu dengan sebaik mungkin.

Senada dengan pendapat di atas Daniel Goleman (Widyahening, 2016) berpendapat pendidikan karakter menjadi penting yang harus diaplikasikan dan disadari. Karakter yang perlu dibangun adalah karakter yang memiliki kemampuan dan kebiasaan untuk memberikan yang terbaik berdasarkan nilai pendidikan. (Boyatzis et al., 2000; Goleman, 2001) mengatakan bahwa pendidikan karakter adalah nilai pendidikan yang terdiri dari 9 nilai dasar yaitu: 1) Tanggungjawab, 2) Rasa hormat, 3) Keadilan, 4) Keberanian, 5) Kejujuran, 6) Kewarganeraan, 7) Disiplin diri, 8) Peduli, 9) Ketekunan.

Nilai yang dikembangkan dalam pendidikan karakter diidentifikasi dari sumber-sumber: (1) agama, (2) pancasila, (3) kebudayaan (4) tujuan pendidikan nasional. Berdasarkan keempat sumber nilai itu, teridentifikasi sejumlah nilai untuk pendidikan budaya dan karakter bangsa. Sejak tahun pelajaran 2011 seluruh tingkat pendidikan di Indonesia harus menyisipkan pendidikan karakter (Listyarti Retno, 2012). Adapun nilai-nilai yang terkandung pendidikan karakter adalah sebagai berikut: a) Religius, b) Jujur, c) Toleransi, d) Disiplin, e) Kerja keras, f) Kreatif, g) Mandiri, h) Demokratis, i) Rasa ingin tahu. j) Semangat kebangsaan, h) Cinta tanah air, j) Menghargai prestasi, k) Bersahabat/Komunikatif, m) Cinta damai, n) Gemar membaca, n) Peduli lingkungan, o) Peduli social, p) Tanggung jawab.

Dari beberapa nilai-nilai pendidikan karakter di atas, dalam penelitian ini, nilai-nilai pendidikan karakter yang akan dikembangkan adalah nilai religius, nilai disiplin dan nilai tanggung jawab.

Karakter pemimpin merupakan merupakan salah satu faktor yang menentukan kesuksesan dan kegagalan seorang pemimpin. Keberhasilan seorang pemimpin didasarkan pada upaya-upaya untuk menjadikan kebiasaan-kebiasaan positif sebagai bahan dari karakter pemimpin (Covey, 1997).

Beberapa teladan yang yang dapat kita lakukan dalam penanaman nilai-nilai karakter pada siswa, yaitu: a) Religius, selalu taat beribadah; b). Disiplin, masuk dan keluar kelas tepat waktu; dan c) Bersahabat/komunikatif, memberikan kesemptan kepada siswa untuk bertanya dan memuji siswa yang bertanya atau menjawab pertanyaan guru (Kemendiknas, 2011).

Sementara dalam sebuah buku yang berjudul Soft Skill Untuk Pendidik (Elfindri et al., 2010), mengatakan bahwa ada beberapa tips untuk mengasah kejujuran anak, yaitu: a) Guru harus selalu menepati setiap pembicaraannya kepada anak didiknya; b) Dalam proses belajar, mengajar ataupun ujian, seorang guru harus tetap menjaga kedisiplinan; c) Seluruh peserta didik harus di beri kesempatan yang merata untuk menyusun kerja secara mandiri dan melaporkan bagaimana proses pekerjaan yang dilakukannya; dan d) Mengoreksi tata cara penulisan, perkataan, dalam konteks kejujuran dalam mengutip atau melaporkan bahan bacaan.

Menurut pendapat yang dikemukakan oleh Aristoteles (Covey, 1997) kita adalah apa yang kita kerjakan ulang-ulang, keunggulan bukanlah suatu perbuatan, melainkan suatu perbuatan, melainkan suatu kebiasaan. Karakter kita pada dasarnya adalah gabungan dari kebiasaan-kebiasaan kita. Proses pembentukan karakter dapat digambarkan sebagai berikut:

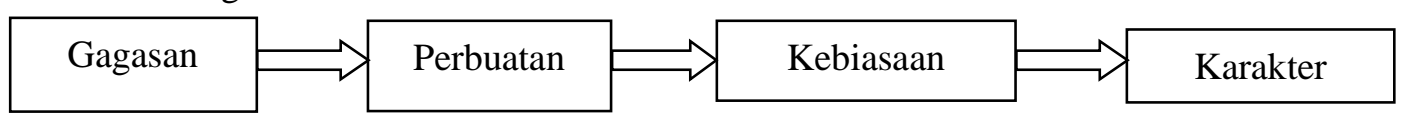

Gambar 1. Alur pembentukan Karakter

Penjelasan berdasarkan gambar di atas adalah gagasan yang kita ketahui akan kita aktualisasikan dalam perbuatan, perbuatan yang dilakukan berulang-ulang akan menjadi suatu kebiasaan, kebiasaan yang dilakukan secara berulang akan membentuk suatu karakter. 
Kedisiplinan berasal dari kata disiplin. Istilah disiplin menurut Macmillan English Dictionary berasal dari bahasa latin "disiplina" yang menunjuk pada kegiatan belajar dan mengajar. Sedangkan isitilah bahasa inggrisnya yaitu "disipline" yang berarti:1) Tertib,taat atau mengendalikan tingkah laku,penguasaan diri, 2) latihan membentuk, meluruskan atau menyempurnakan sesuatu, sebagai kemampuan mental atau karakter moral, 3) Hukuman yang diberikan untuk melatih atau memperbaiki, 4) Kumpulan atau sistem-sistem atau peraturan-peraturan bagi tingkah laku.

Disiplin adalah suatu kondisi yang tercipta dan terbentuk melalui proses dari serangkaian perilaku yang menunjukkan nilai-nilai ketaatan, kepatuhan, kesetiaan, keteraturan dan ketertiban. Disiplin akan membuat seseorang tahu dan dapat membedakan hal-hal apa yang seharusnya dilakukakan, yang wajib dilakukan, yang boleh dilakukan, yang sepatutnya dilakukan. Bagi seseorang yang berdisiplin, karena sudah menyatu dalam dirinya, maka sikap atau perbuatan yang dilakukan bukan lagi dirasakan sebagai beban, namun sebaliknya akan membebani dirinya apabila ia tidak berbuat disiplin. Nilai-nilai kepatuhan telah menjadi bagian dari perilaku dalam kehidupannya. Disiplin yang mantap pada hakikatnya akan tumbuh dan terpancar dari hasil kesadaran manusia. Sebaliknya, disiplin yang tidak bersumber dari kesadaran hati nurani akan menghasilkan disiplin yang lemah dan tidak akan bertahan lama, atau disiplin yang statis, tidak hidup ((Djojonegoro, 1998).

Disiplin apabila dilihat dari segi bahasanya itu sendiri adalah latihan ingatan dan watak untuk menciptakan pengawasan (kontrol diri) atau bisa juga kebiasaan mematuhi ketentuan dan perintah. Jadi arti pengertian disiplin secara lengkap adalah kesadaran untuk melakukan sesuatu pekerjaan dengan tertib dan sesuai dengan peraturan-peraturan yang berlaku dengan penuh tanggungjawab tanpa paksaan dari siapapun. Suratman memberikan pengertian disiplin sebagai suatu ketaatan yang sungguh-sungguh dan didukung oleh kesadaran untuk menuaikan tugas dan kewajiban serta sikap dan perilaku sesuai dengan aturan atau tata kelakuan yang semestinya didalam suatu lingkungan tertentu (Suratman, 1999).

Kedisiplinan adalah hal mentaati tata tertib disegala aspek kehidupan, baik agama, budaya, pergaulan, sekolah lain-lain. Dengan kata lain, kedisiplinan merupakan kondisi yang tercipta dan terbentuk melalui proses dari serangkaian perilaku individu yang menunjukkan nilai-nilai ketaatan, kesetiaan, keteraturan, dan ketertiban. Hal ini berdasarkan pada pengertian dalam Kamas Besar Bahasa Indonesia, yang berasal dari kata disiplin berarti kepatuhan dan ketaatan kepada peraturan tata tertib dan sebagainya. (Dewantara, 1967) menyebutkan bahwa disiplin tak lain adalah peraturan tata tertib yang dilakukan secara tegas dan ketat. Dari pengertian dasar tersebut, kemudian berlanjut dengan istilah kedisiplinan yang dapat diartikan sebagai keadaan yang taat kepada peraturan tata tertib.

Sedangkan menurut (Trisnawati et al., 2018) bahwa, kedisiplinan adalah kesetiaan dan ketaatan seseorang, norma-norma, instruksi-instruksi, yang dinyatakan berlaku untuk orang atau orang tersebut. Dari beberapa pendapat tersebut terlihat jelas bahwa pengertian disiplin mengandung beberapa unsur yakni ketaatan, pengetahuan, kesadaran, ketertiban, dan perasaan senang didalam menjalankan tugas dan mematuhi atau mentaati segala peraturan-peraturan perundangan yang dinyatakan berlaku. Hasibuan (2016) menyatakan bahwa faktor yang menyebabkan kedisiplinan antara lain: 1) Tujuan dan kemampuan. 2) Keteladanan pemimpin. 3) Balas jasa. 4) Keadilan. 5) Pengawasan melekat. 6) Sanksi hukuman. 7) Ketegasan. 8) Hubungan kemanusian.

Berdasarkan teori di atas maka dapat disimpulkan bahwa indikator kedisiplinan merupakan meliputi kemampuan individu dalam menjalankan perilaku yang bersifat keteladanan dengan adanya adanya pemberian sanksi hukuman yang tegas atas peraturan yang berlaku dalam pembinaan hubungan kekeluargaan yang harmonis. Kedisiplinan menjadi alat yang ampuh dalam mendidik karakter. Kedisiplinan akan menghasilkan banyak kesuksesan jika kedisiplinan itu sendiri ditegakan. Sebaliknya, banyak upaya membangun sesuatu tidak berhasil karena kurang atau tidak disiplin. Penegakan disiplin antara lain dapat dilakukan dengan beberapa cara: 1) Peningkatan motivasi, 2) Pendidikan dan latihan, 3) Kepemimpinan, 4) Penegakan aturan, 5) Penerapan reward dan punishment. 
Belajar adalah suatu bagian dari pendidikan yang diterapkan agar dapat membentuk karakter peserta didik. Usia siswa sekolah dasar pada umumnya memiliki sifat khas yang ditunjukan untuk berkuasa dan ekstravers. Sikap, tingkah laku, dan perbuatan anak sekolah dasar pun ditujukan untuk berkuasa, memiliki keinginan menjadi "paling" dari anak yang lain. siswa sekolah dasar juga memiliki sifat ekstravet yang berorientasi mendorong siswa untuk menyaksikan keadaan-keadaan diluar dunia, diluar dirinya dan mencari teman sebaya untuk memenuhi kebutuhan psikisnya.

Di setiap lembaga pendidikan selain menerapkan dan mengajarkan pendidikan karakter, pendidik juga menekankan adanya kedisiplinan yang harus di taati oleh para siswa disekolah maupun diluar sekolah. Seorang yang mempunyai karakter baik tentunya selalu mendisiplinkan dirinya sesuai sesuai dengan peraturan yang sudah diterapkan dalam suatu organisasi atau lembaga. Di lemabaga pendidikan, guru menerapkan nilai pendidikan karakter disekolah melalui kegiatan sekolah maupun mata pelajaran. (Lickona, 1991) mendefenisikan pendidikan karakter sebagai upaya yang dirancang secara sengaja untuk untuk memperbaiki karakter para siswa. Jika nilai pendidikan karakter yang diterapkan dan dikembangkan disekolah dapat berhasil, maka peserta didik akan mempunyai karakter yang baik sehingga peserta didik akan lebih menekankan disiplin pada dirinya. Selain itu kesuksesan seseorang tidak semata-mata ditentukan oleh pengetahuan dan keretampilan teknis, melainkan juga oleh karakter yang dimiliki. Orang yang memiliki karakter yang baik pasti akan menerapkan kedisiplinan pada dirinya.

\section{METODE PENELITIAN}

Jenis penelitian yang digunakan merupakan jenis penelitian korelasi dengan menggunakan pendekatan kuantitatif (Arikunto, 2006). Penelitian korelasi merupakan suatu bentuk penelitian yang melibatkan tindakan pengumpulan data guna menentukan, apakah ada pengaruh dan tingkat pengaruh antara dua variabel atau lebih (Sukardi, 2003). Penelitian dilakukan selama bulan Pebruari 2021, di Sekolah Dasar Gugus 01 kecamatan Detukeli yang terdiri dari SDK Magekoba, SDI Aedari, SDN Kurupoke dan SDK Gaibhabha, dengan Jumlah Guru sebanyak 30 orang yang keseluruhannya menjadi subyek penelitian ini. Teknik pengumpulan data yang dilakukan dengan Kuesioner yang berisi seperangkat pertanyaan atau pernyataan tertulis kepada responden untuk dijawabinya. Dalam kuesioner ini peneliti menggunakan skala likert dengan variabel yang diukur dijabarkan menjadi indikator variabel. tingkat validitas instrumen untuk variabel Pendidikan karakter berkisar dari 1,805 - 8,197.dan tingkat validitas untuk variabel Kedisiplinan berkisar dari 1,796 - 7,778. Untuk analisis data tingkat pendidikan karakter (X) dan dan Kedisiplinan (Y) peneliti menggunakan analisis deskriptif, sedangkan menentukan pengaruh pendidikan karakter terhadap kedisiplinan peserta didik, peneliti menggunakan analisis regresi linear sederhana yang digunakan untuk mengukur pengaruh lebih dari satu variabel predictor (variabel bebas) terhadap variabel terikat.

$$
\mathrm{Y}=\mathrm{a}+\mathrm{Bx}
$$

Dimana:

$$
\begin{array}{ll}
\mathrm{Y}=\text { Variabel Terikat (kedisiplinan) } & \mathrm{X}=\text { variabel bebas (Pendidikan Karakter) } \\
\mathrm{a}=\text { konstanta } & \mathrm{B}=\text { koefisien regresi (nilai peningkatan ataupun penurunan) }
\end{array}
$$

$$
\begin{aligned}
P=\frac{f}{n} \times 100 \% \\
\mathrm{P}=\text { presentase yang dicari } \quad \mathrm{F}=\text { frekuensi } \quad \mathrm{N}=\text { number of cases }
\end{aligned}
$$

Analisis korelasi metode statisitik yang digunakan untuk mengukur besarnya hubungan linear antara dua variabel atau lebih. Uji korelasi populasi ( $p$ ) berkisar pada interval $-1 \leq p \leq 1$. Jika korelasi bernilai positif, maka hubungan antara dua variabel bersifat searah. Sebaliknya, jika korelasi bernilai negatif, maka hubungan antara dua variabel bersifat berlawanan arah (Sugiyono, 2017). Misalkan korelasi sampel antara Variabel X dan $\mathrm{Y}(\mathrm{rX}, \mathrm{Y})$ berinilai positif mengartikan bahwa jika nilai $\mathrm{X}$ naik maka nilai $\mathrm{Y}$ juga naik, sedangkan jika 
3682 Pengaruh Pendidikan Karakter terhadap Kedisiplinan Peserta Didik di Sekolah Dasar - Ferdinandus Etuasius Dole

DOI: https://doi.org/10.31004/edukatif.v3i6.1026

nilai X turun maka nilai Y juga turun. Sedangkan korelasi sampel antara Variabel X dan Y (rX, Y),bernilai negatif mengartikan bahwa jika nilai $\mathrm{X}$ naik maka nilai $\mathrm{Y}$ juga turun, sedangkan jika nilai $\mathrm{X}$ turun maka nilai Y naik.

Distribusi (Tabel t) untuk $\alpha=0,05$ dan derajat kebebasan $(\mathrm{dk}=\mathrm{n}-2)$. Kaidah keputusan:jika thitung>ttabelberarti valid sebaliknya thitung <ttabel berarti tidak valid (Riduwan, 2017) jika instrumen itu valid, maka lihat kriteria penafsiran mengenai indeks korelasinya (r) sebagai berikut:

Antara $0,80-1,000$ : sangat tinggi

Antara $0,60-0,799$ : tinggi

Antara 0,40-0, 599 : cukup

Antara 0,20-0, 399 : rendah

Antara 0,00-0, 199 : sangat rendah (tidak valid).

\section{HASIL PENELITIAN}

Penelitian ini dilakukan di SD Gugus 01 Kecamatan Detukeli Kabupaten Ende. Sampel pada penelitian ini adalah guru- guru di SD Gugus 01 Kecamatan Detukeli sebanyak 30 orang yang terdiri dari 4 orang guru laki-laki dan 26 guru perempuan. Penelitian ini bertujuan untuk mengetahui ada tidaknya pengaruh pendidikan karakter terhadap kedisiplinan di Sekolah Dasar SD Gugus 01 Kecamatan Detukeli.

\section{Deskripsi Variabel Pendidikan Karakter}

Variabel pendidikan karakter diukur melalui angkte yang terdiri dari 30 butir instrumen dengan skala likert yang terdiri dari 4 alternatif jawaban dengan jumlah 15 responden. Berdsarkan penelitian yang telah dilakukan, diperoleh rekapitulasi hasil pengisian angket dengan menggunakan program SPSS for windows versi 17.00. Hasil pengolahan data statistik untuk variabel pendidikan karakter diperoleh rata-rata dengan standar deviasi yang tertera pada tabel 4.1 berikut.

\section{Tabel 1}

\begin{tabular}{|c|c|c|}
\hline \multicolumn{3}{|c|}{ Analisis Deskriptif Statistics pendidikan karakter (X } \\
\hline \multirow[t]{2}{*}{$\mathbf{N}$} & Valid & 30 \\
\hline & Missing & 0 \\
\hline \multicolumn{2}{|l|}{ Mean } & 114,6333 \\
\hline \multicolumn{2}{|c|}{ Median } & 114,0000 \\
\hline \multicolumn{2}{|l|}{ Mode } & 113,00 \\
\hline \multicolumn{2}{|c|}{ Std. Deviation } & 2,20475 \\
\hline \multicolumn{2}{|l|}{ Range } & 8,00 \\
\hline \multicolumn{2}{|c|}{ Minimum } & 111,00 \\
\hline \multicolumn{2}{|c|}{ Maximum } & 119,00 \\
\hline \multicolumn{2}{|l|}{ Sum } & 3439,00 \\
\hline
\end{tabular}

Berdasarkan hasil olah data pada tabel di atas diperoleh skor tertinggi $($ maksimum $)=119,00 ;$ skor terendah $($ minimum $)=111,00 ;$ nilai,rata-rata $($ mean $)=114,6633 ;$ range $=8,00 ;$ median $=114,0000 ;$ mode $=$ 113,$00 ;$ standar deviasi $=2,20475 ;$ sum $=3439,00$. Selanjutnya hasil analisis jawabn responden dibuat analisis frekuensi dengan menggunakan SPSS for windows fersi 17.00 sebagai berikut:

Tabel 2

Frekuensi Pendidikan Karakter (X)

\begin{tabular}{|c|c|c|c|c|c|}
\hline & & Frequency & Percent & Valid Percent & $\begin{array}{l}\text { Cumulative } \\
\text { Percent }\end{array}$ \\
\hline \multirow[t]{4}{*}{ Valid } & 111,00 & 1 & 3,3 & 3,3 & 3,3 \\
\hline & 112,00 & 3 & 10,0 & 10,0 & 13,3 \\
\hline & 113,00 & 9 & 30,0 & 30,0 & 43,3 \\
\hline & 114,00 & 3 & 10,0 & 10,0 & 53,3 \\
\hline
\end{tabular}


3683 Pengaruh Pendidikan Karakter terhadap Kedisiplinan Peserta Didik di Sekolah Dasar - Ferdinandus Etuasius Dole

DOI: https://doi.org/10.31004/edukatif.v3i6.1026

\begin{tabular}{lllll}
\hline 115,00 & 3 & 10,0 & 10,0 & 63,3 \\
116,00 & 5 & 16,7 & 16,7 & 80,0 \\
117,00 & 2 & 6,7 & 6,7 & 86,7 \\
118,00 & 2 & 6,7 & 6,7 & 93,3 \\
119,00 & 2 & 6,7 & 6,7 & 100,0 \\
Total & $\mathbf{3 0}$ & $\mathbf{1 0 0 , 0}$ & $\mathbf{1 0 0 , 0}$ & \\
\hline
\end{tabular}

Dari tabel di atas, hasil jawaban responden dibagi dalam kelas-kelas berikut. Untuk menentukan jumlah kelas interval (banyaknya kelas) dapat dihitung dengan rumus Struges (Riduwan, 2017) yaitu 1+3,3 $\log$ n, dimana $\mathrm{n}$ adalah subjek penelitian (reponden), maka dapat diperoleh $1+3,3 \log 30=1+3,3(1,477)=1+4,874=$ 5,874 dibulatkan menjadi 6 . Rentang data $=119-111=8$. Maka 8:6 $=1,3$ dibulatkan menjadi 1 . Karena data ini tidak ada interval atau data tunggal maka setiap data berada pada kelasnya masing-masing.

Selanjutnya menurut (Iriani \& Soeharto, 2015) variabel pendidikan karakter digolongkan kedalam kategori dengan ketentuan sebagai berikut:

$\begin{array}{ll}\text { Sangat Tinggi } & =\mathrm{X} \geq \mathrm{Mi}+1,5(\mathrm{Sbi}) \\ \text { Tinggi } & =\mathrm{Mi} \leq \mathrm{X}<\mathrm{Mi}+1,5(\mathrm{Sbi}) \\ \text { Sedang } & =\mathrm{Mi}-1,5(\mathrm{Sbi}) \leq \mathrm{X}<\mathrm{Mi} \\ \text { Rendah } & =\mathrm{X}<\mathrm{Mi}-1,5(\mathrm{Sbi})\end{array}$

\section{Keterangan:}

$\mathrm{X}=$ Skor Responden Mi $=$ Mean Ideal

Sbi $\quad=$ Simpangan Baku Ideal

Mi $\quad=1 / 2(X$ maks $+X \min )=1 / 2(119+111)=115$

Sbi $\quad=1 / 6(X \max -X \min )=1 / 6(119-111)=1,3$

Tabel 3

Distribusi Kecenderungan Pendidikan Karakter

\begin{tabular}{cllll}
\hline No. & Interval & Frekuensi & Presentase & Kategori \\
\hline 1. & $\mathrm{X} \geq 116,95$ & 4 & 13,3 & Sangat tinggi \\
2. & $115 \leq \mathrm{X} \leq 116,95$ & 7 & 23,3 & Tinggi \\
3. & $113,05 \leq \mathrm{X}<115$ & 6 & 20 & Sedang \\
4. & $\mathrm{X}<113,05$ & 12 & 40 & Rendah \\
\hline Total & & $\mathbf{3 0}$ & $\mathbf{1 0 0}$ & \\
\hline
\end{tabular}

Berdasarkan tabel presentase jawaban responden tentang Pendidikan Karakter dapat disimpulkan dengan total skor yang terkumpul sebesar $100 \%$. Dilihat dari tabel 4.3 presentase sebesar 13,3\% sebanyak 4 orang berada pada kategori sangat tinggi, kategori tinggi 23,3\% sebanyak 7 orang, kategori sedang 20\% sebanyak 6 orang, kategori rendah $40 \%$ sebanyak 12 orang.

\section{Deskripsi Variabel kedisiplinan (Y)}

Variabel interaksi sosial diukur melalui angket yaitu terdir dari 30 butir instrumen dengan skala likert yang terdiri dari 4 alternatif jawaban dengan jumlah 15 responden. Berdasarkan penelitian yang telah dilakukan, diperoleh rekapitulasi hasil pengisian angket dengan menggunakan program SPSS for windows versi 17. Hasil pengolahan data statistic untuk variable interaksi social diperoleh rata-rata dan standar deviasi seperti yang tertera pada table.

Tabel 4

Analisis Deskriptif Statistics Kedisiplinan (Y)

$\begin{array}{rll}\mathrm{N} & \text { Valid } & 30 \\ & \text { Missing } & 0 \\ \text { Mean } & & 115,1333\end{array}$


3684 Pengaruh Pendidikan Karakter terhadap Kedisiplinan Peserta Didik di Sekolah Dasar - Ferdinandus Etuasius Dole

DOI: https://doi.org/10.31004/edukatif.v3i6.1026

\begin{tabular}{ll} 
Median & 115,0000 \\
Mode & 117,00 \\
Std. Deviation & 2,04658 \\
Range & 7,00 \\
Minimum & 112,00 \\
Maximum & 119,00 \\
Sum & 3454,00 \\
\hline
\end{tabular}

Berdasarkan hasil olah data pada tabel 4.3 di peroleh skor tertinggi $($ maksimum $)=11$;skor terendah $($ minumum $)=112 ;$ rata-rata $($ mean $)=115,1333 ;$ range $=7 ;$ median $=115 ;$ mode $=117 ;$ standar deviasi $=$ 2,04658; sum $=3454,00$. Selanjutnya hasil analisis jawaban responden dibuat analisis frekuensi dengan menggunakan SPSS for windows versi 17.00 sebagai berikut:

Tabel 5

Frekuensi Kedisiplinan Y)

\begin{tabular}{|c|c|c|c|c|c|}
\hline \multirow{10}{*}{ Valid } & & Frequency & Percent & Valid Percent & Cumulative Percent \\
\hline & 112,00 & 3 & 10,0 & 10,0 & 10,0 \\
\hline & 113,00 & 5 & 16,7 & 16,7 & 26,7 \\
\hline & 114,00 & 5 & 16,7 & 16,7 & 43,3 \\
\hline & 115,00 & 4 & 13,3 & 13,3 & 56,7 \\
\hline & 116,00 & 3 & 10,0 & 10,0 & 66,7 \\
\hline & 117,00 & 6 & 20,0 & 20,0 & 86,7 \\
\hline & 118,00 & 3 & 10,0 & 10,0 & 96,7 \\
\hline & 119,00 & 1 & 3,3 & 3,3 & 100,0 \\
\hline & Total & 30 & 100,0 & 100,0 & \\
\hline
\end{tabular}

Dari table di atas peneliti kemudian membagi hasil jawaban responden pada variabel kedisiplinan peserta didik kedalam kelas-kelas berikut. Untuk menentukan jumlah kelas interval dihitung dengan rumus struges (Riduwan, 2017) yaitu $1+3,3 \log \mathrm{n}$,dimana $\mathrm{n}$ adalah subjek penelitian (responden), maka dapat diperoleh $1+3,3 \log 30=1+3,3(1,477)=1+4,87=5,87$ dibulatkan menjadi 6 . Rentang data sebesar 119-112 =7. Maka 7:6 =1,16 dibulatkan menjadi 1 . Karena data ini tidak ada intervalnya atau data tunggal Maka setiap data berada pada kelasnya masing-masing.

Selanjutnya menurut (Iriani \& Soeharto, 2015), variabel kedisiplinan digolongkan ke dalam kategori dengan ketentuan sebagai berikut:

$$
\begin{array}{ll}
\text { Sangat Tinggi } & =\mathrm{X} \geq \mathrm{Mi}+1,5(\mathrm{Sbi}) \\
\text { Tinggi } & =\mathrm{Mi} \leq \mathrm{X}<\mathrm{Mi}+1,5(\mathrm{Sbi}) \\
\text { Sedang } & =\mathrm{Mi}-1,5(\mathrm{Sbi}) \leq \mathrm{X}<\mathrm{Mi} \\
\text { Rendah } & =\mathrm{X}<\mathrm{Mi}-1,5(\mathrm{Sbi})
\end{array}
$$

\section{Keterangan:}

$\mathrm{X}=$ Skor Responden $\mathrm{Mi}=$ Mean Ideal

Sbi = Simpangan Baku Ideal

$$
\begin{array}{llll}
\text { Mi } & =1 / 2(X \text { maks }+X \min ) & =1 / 2(119+112) & =115,5 \\
\text { Sbi } & =1 / 6(X \text { maks }-X \text { min }) & =1 / 6(119-112) & =1,6
\end{array}
$$

Tabel 6

Distribusi Kecenderungan Kategori Kedisiplinan.

\begin{tabular}{lllll}
\hline No. & Interval & $\begin{array}{l}\text { Frekuens } \\
\mathbf{i}\end{array}$ & $\begin{array}{l}\text { Presentase } \\
(\boldsymbol{\%})\end{array}$ & Kategori \\
\hline 1. & $\mathrm{X} \geq 117,9$ & 4 & 13,3 & Sangat tinggi \\
2. & $115,5 \leq \mathrm{X}<117,9$ & 9 & 30 & Tinggi \\
1. & $113,1 \leq \mathrm{X}<115,5$ & 9 & 30 & Sedang \\
4. & $\mathrm{X}<113,1$ & 8 & 26,7 & Rendah \\
\hline
\end{tabular}

Edukatif : Jurnal Ilmu Pendidikan Vol 3 No 6 Tahun 2021 p-ISSN 2656-8063 e-ISSN 2656-8071 
3685 Pengaruh Pendidikan Karakter terhadap Kedisiplinan Peserta Didik di Sekolah Dasar - Ferdinandus Etuasius Dole

DOI: https://doi.org/10.31004/edukatif.v3i6.1026

$\begin{array}{lll}\text { Total } & 30 & 100\end{array}$

Berdasarkan tabel presentase jawaban responden tentang kedisiplinan dapat disimpulkan dengan total skor yang terkumpul sebesar 100\%. Dilihat dari tabel 4.6 presentase sebesar 13,3\% sebanyak 4 orang berada pada kategori sangat tinggi. Kategori tinggi $30 \%$ sebanyak 9 orang, kategori sedang 30\% sebanyak 9 orang, kategori rendah $26,7 \%$ sebanyak 8 0rang

\section{Pengujian Hipotesis}

Setelah dilakukan uji prasyarat dan diketahui data terdistribusi normal serta liniear, dilanjutkan uji hipotesis guna mengetahui adanya korelasi antar variabel. Pengujian hipotesis dalam penelitian ini menggunakan korelasi Product moment. Hipotesis yang diajukan dalam korelasi Product Moment adalah adanya pengaruh antara pendidikan karakter terhadap kedisiplinan peserta didik SD Gugus 01 Kecamatan Detukeli.

\section{Tabel 7}

Hasil Uji Hipotesis

Model Summary

\begin{tabular}{lllllllllll}
\hline Model R & R Square & $\begin{array}{l}\text { Adjusted R } \\
\text { Square }\end{array}$ & $\begin{array}{l}\text { Std. Error of } \\
\text { the Estimate }\end{array}$ & $\begin{array}{l}\text { Change Statistics } \\
\text { R Square } \\
\text { Change }\end{array}$ & F Change & df1 & df2 & Sig. F ChangeWatson \\
\hline 1 &, $730^{a}$ &, 532 &, 516 & 1,42445 &, 532 & 31,863 & 1 & 28 &, 000 & 2,336 \\
\hline
\end{tabular}

a. Predictors: (Constant), Pendidikan_Karakter

b. Dependent Variable: Kedisiplinan

Tabel di atas menjelaskan besarnya nilai korelasi/hubungan $(\mathrm{R})$ sebesar 0,730 dan presentase pengaruh variabel bebas terhadap variabel terikat yang disebu koofisien determinasi yang merupakan hasil dari pengkuadratan R. Dari hasil olahan data diperoleh koefisien determinasi $\left(R^{2}\right)$ sebesar 0,532 . Maka dapat disimpulkan bahwa ada pengaruh variabel bebas ( pendidikan karakter) terhadap variabel terikat (kedisiplinan) sebesar $53,2 \%$ sedangkan sisanya $46,8 \%$ dipengaruhi oleh variabel lain.

\section{Tabel 8}

\begin{tabular}{|c|c|c|c|c|c|c|}
\hline \multicolumn{7}{|c|}{$\begin{array}{c}\text { Tabel } 8 \\
\text { Anova }\end{array}$} \\
\hline Model & & Sum of Squares & Df & Mean Square & $\mathrm{F}$ & Sig. \\
\hline \multirow[t]{3}{*}{1} & Regression & 64,653 & 1 & 64,653 & 31,863 &, $000^{b}$ \\
\hline & Residual & 56,814 & 28 & 2,029 & & \\
\hline & Total & 121,467 & 29 & & & \\
\hline
\end{tabular}

a. Dependent Variable: Kedisiplinan

b. Predictors: (Constant), Pendidikan_Karakter

Dari tabel di atas dapat dijelaskan bahwa ada pengaruh yang nyata (signifikan) variabel Pendidikan Karakter (X) terhadap Variabel Interaksi Sosial (Y). Berdasarkan hasil olahan data tersebut terlihat bahwa $F_{\text {hitung }}$ adalah 31,863 dengan tingkat signifikan/probalitas $0,000<0,005$, maka model regresi dapat dipakai untuk memprediksi Variabel Kedisiplinan.

Tabel 9

\section{Coefficients}

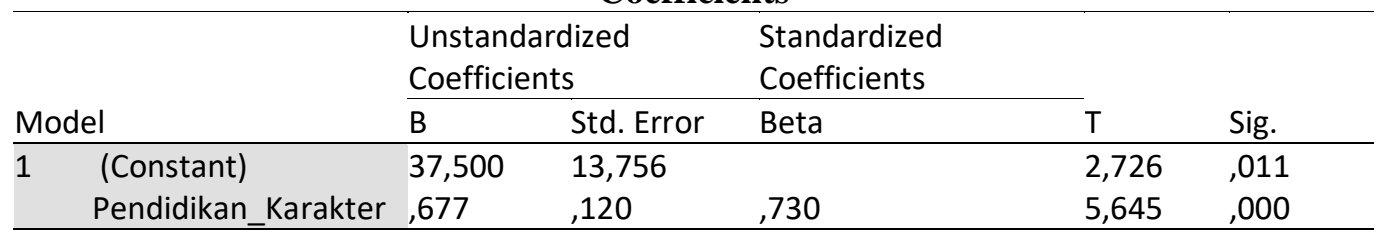

a. Dependent Variable: Kedisiplinan 
3686 Pengaruh Pendidikan Karakter terhadap Kedisiplinan Peserta Didik di Sekolah Dasar - Ferdinandus Etuasius Dole

DOI: https://doi.org/10.31004/edukatif.v3i6.1026

Pada tabel Coefficients ${ }^{a}$ pada kolom B pada Constant (a) adalah 37, 500, sedangkan nilai Kedisiplinan (b) adalah 0,677 sehingga persamaan regresi dapat ditulis $\mathbf{Y}=\mathbf{a + b X}$ atau 37,500+0,677X. Artinya ada pengaruh yang positif dan signifika dari variabel $X$ terhadap variabe

Tabel 10

Hasil Uji Korelasi Variabel X dan Y

Correlations

\begin{tabular}{llll}
\hline & & \multicolumn{2}{l}{ Pendidikan_Karakter Kedisiplinan } \\
\hline Pendidikan_Karakter & Pearson Correlation & 1 &, $730^{* *}$ \\
& Sig. (2-tailed) & &, 000 \\
& $\mathrm{~N}$ & 30 & 30 \\
\multirow{4}{*}{ Kedisiplinan } & Pearson Correlation &, $730^{* *}$ & 1 \\
& Sig. (2-tailed) &, 000 & 30 \\
& $\mathrm{~N}$ & 30 & \\
**. Correlation is significant at the 0.01 level (2-tailed).
\end{tabular}

Dari tabel di atas, menunjukkan bahwa nilai korelasi pearson X terhadap Y sebesar 0,000 dan bernilai positif sehingga hubungan variabel $\mathrm{X}$ dan $\mathrm{Y}$ adalah signifikan atau dengan kata lain diketahui pengaruh variabel $X$ terhadap Y nilai Signifikan $0,000<0,05$ yang berarti terdapat korelasi signifikan.

\section{Pendidikan Karakter}

Penerapan pendidikan karakter yang dijalankan untuk membentuk kedisiplinan siswa yaitu Penerapan Pendidikan Karakter di sekolah dasar dilakukan pada kegiatan pembelajaran, pengembangan budaya sekolah, dan pusat kegitan belajar, kegiatan ekstrakurikuler dan kegiatan keseharian di rumah dan di masyarakat. Pendidikan karakter disekolah dapat diterapkan pada semua mata pelajaran. Setiap mata pelajaran yang berkaitan dengan norma-norma perlu dikembangkan dan dikaitkan dengan kehidupan sehari-hari.

Berdasarkan data jawaban responden tentang Pendidikan Karakter dengan rata-rata sebesar 114,63. Berdasarkan rata-rata bila disandingkan dengan tabel 3 Distribusi Kecenderungan variabel X Pendidikan Karakteri, maka dapat disimpulkan bahwa pendidikan karakter di gugus 01 Kecamatan Detukeli berada pada kategori cenderung Sedang.

\section{Kedisiplinan}

Disiplin adalah sikap seseorang untuk mentaati aturan atau tata tertib yang berlaku di dalam satu organisasi berdasarkan kesadaran yang ada pada dirinya untuk membentuk perilaku yang sesuai dengan nilainilai yang ditentukan. Implementasi pendidikan karakter yang diterapkan disekolah seperti adanya kegiatan senyum, salam, sapa yang dilakukan setiap pagi kegiatan literasi 15 menit sebelum memulai pelajaran, cek kerapian seragam setiap pagi. Dengan demikian, diharapakan para siswa bisa menerapkan nilai pendidikan karakter dalam kehidupan sehari-hari baik didalam sekolah maupun diluar sekolah terutama mendisiplinkan diri, karena dengan mendisiplinkan diri secara baik akan menciptakan sumber daya manusia yang berkualitas. Selain itu tujuan dari pendidikan karakter adalah untuk membentuk, menanamkan, memfasilitasi dan mengembangkan nilai-nilai positif pada anak sehingga menjadi pribadi yang unggul dan bermartabt.

Berdasarkan hasil jawaban dari responden tentang Kedisiplinan dapat disimpulkan dengan total skor yang terkumpul sebesar 3454, dan rata-rata 115,13, bila disandingkan dengan Tabel 6. Distribusi Kecenderungan Kategori Kedisiplinan maka dapat disimpulkan bahwa kedisiplinan peserta didik di gugus 01 Kecamatan Detukeli berada pada kategori cenderung Sedang.

\section{Pengaruh Pendidikan Karakter terhadap Kedisiplinan.}

Pendidikan karakter merupakan pemberian tuntutan atau upaya yang dilakukan untuk merubah, memperbaiki sikap serta tingkah laku peserta didik agar dapat berperilaku yang baik. Disetiap lembaga 
3687 Pengaruh Pendidikan Karakter terhadap Kedisiplinan Peserta Didik di Sekolah Dasar - Ferdinandus Etuasius Dole

DOI: https://doi.org/10.31004/edukatif.v3i6.1026

pendidikan, pendidik juga memberikan pendidikan karakter yang berisi tentang nilai-nilai pendidikan karakter melalui mata pelajaran maupun budaya yang ada di Sekolah agar siswa dapat membentuk dan mempunyai karakter yang baik sesuai dengan nilai pendidikan karakter yang ditetapkan oleh (Kemendiknas, 2010).

Kedisiplinan Peserta didik dapat dibentuk dengan mengaplikasikan atau menerapkan pendidikan karakter di Sekolah dasar dilakukan pada kegiatan pembelajaran, pengembangan budaya sekolah ,dan pusat kegiatan belajar, kegiatan ekstrakurikuler dan kegiatan keseharian di rumah dan di masyarakat.

Berdasarkan hasil Analisis Regresi Sederhana untuk mencari pengaruh pendidikan karakter terhadap kedisiplinan peserta didik SD Gugus 01 Kecamatan Detukeli diperoleh koofesien korelasi $(\mathrm{R})=0,730$ yang menyatakan bahwa indeks korelasi ( $\mathrm{r}$ ) X terhadap $\mathrm{Y}$ adalah tinggi dengan pengaruh sebesar $\left(\mathrm{R}^{2}\right) \quad 0,532$ atau 53,2\% Hal ini berarti Pendidikan Karakter memberi pengaruh terhadap Kedisiplinan sebesar 53,2\% . Hal tersebut berarti koefesien determinasi parsial yang didapatkan dari perhitungan yaitu sebanyak $53,2 \%$. sedangkan sisanya $46,8 \%$ dipengaruhi oleh faktor lain yang tidak diteliti. Selanjutnya diketahui nilai F berada pada signifikan 0,000. Nilai ini lebih kecil $0,005(0,000<0,05)$. Hal ini berarti hipotesis diterima atau dapat disimpulkan bahwa pengaruh pendidikan karakter berpengaruh secara signifikan terhadap kedisiplinan peserta didik.

\section{KESIMPULAN.}

Berdasarkan hasil penelitian dan pembahasan maka dapat disimpulkan hal-hal sebagai berikut: 1) pendidikan karakter peserta didik SD Gugus 01 Kecamatan Detukeli berada pada kategori cenderung Sedang; 2) tingkat kedisiplinan peserta didik SD Gugus 01 Kecamatan Detukeli berada pada kategori cenderung Sedang.; dan 3) Ada pengaruh positif dan signifikan dari pendidikan karakter terhadap kedisiplinan peserta didik SD Gugus 01 Kecamatan Detukeli, yang ditunjuk dengan koofesien korelasi $(\mathrm{R})=0,730$ yang menyatakan bahwa indeks korelasi ( $\mathrm{r}$ ) $\mathrm{X}$ terhadap $\mathrm{Y}$ adalah tinggi dengan pengaruh sebesar $\left(\mathrm{R}^{2}\right) \quad 0,532$ atau 53,2\% Hal ini berarti Pendidikan Karakter memberi pengaruh terhadap Kedisiplinan sebesar 53,2\% . Hal tersebut berarti koefesien determinasi parsial yang didapatkan dari perhitungan yaitu sebanyak 53,2\%. sedangkan sisanya 46,8\% dipengaruhi oleh faktor lain yang tidak diteliti. Selanjutnya diketahui nilai $\mathrm{F}$ berada pada signifikan 0,000. Nilai ini lebih kecil $0,005(0,000<0,05)$. Hal ini berarti hipotesis diterima atau dapat disimpulkan bahwa pengaruh pendidikan karakter berpengaruh secara signifikan terhadap kedisiplinan peserta didik.

\section{DAFTAR PUSTAKA}

Amri, S., Jauhari, A., \& Elisah, T. (2011). Implementasi pendidikan karakter dalam pembelajaran. Jakarta: PT. Prestasi Pustakaraya.

Amri Sofan. (2011). Implementasi Pendidikan Karakter Dalam Pembelajaran. PT Prestasi Pustakaraya.

Arikunto, S. (2006). Prosedur penelitian suatu pendekatan. Jakarta: Rineka Cipta.

Boyatzis, R. E., Goleman, D., \& Rhee, K. (2000). Clustering competence in emotional intelligence: Insights from the Emotional Competence Inventory (ECI). Handbook of Emotional Intelligence, 99(6), 343-362.

Counts, C. (2004). The six pillars of character. Retrieved January, 12, 2015.

Covey, S. R. (1997). Kepemimpinan Yang Berprinsip. Binarupa Aksara.

Dewantara, K. H. (1967). Ki Hajar Dewantara. Jogjakarta: Majelis Leluhur Taman Siswa.

Djojonegoro, W. (1998). Pedoman Pelaksanaan Disiplin Nasional dan Tata Tertib Sekolah. Mini Jaya Abadi.

Elfindri, D. K. K., Wello, M. B., Tobing, P., Yanti, F., Zein, E. E., \& Indra, R. (2010). Soft skills untuk Pendidik. Baduose Media: Jakarta.

Goleman, D. (2001). Kecerdasan Emosional (Alih Bahasa: T. Hermaya). Gramedia Pustaka Utama. 
3688 Pengaruh Pendidikan Karakter terhadap Kedisiplinan Peserta Didik di Sekolah Dasar - Ferdinandus Etuasius Dole

DOI: https://doi.org/10.31004/edukatif.v3i6.1026

Hasibuan, M. S. . (2016). Manajemen Sumber Daya Manusia (Edisi Revi). Penerbit PT Bumi Aksara.

Iriani, D. S., \& Soeharto, S. (2015). Evaluasi pelaksanaan praktik kerja industri siswa kompetensi keahlian jasa boga SMK N 3 Purworejo. Jurnal Pendidikan Teknologi Dan Kejuruan, 22(3), 274-290.

Kemendiknas. (2010). Desain Induk Pendidikan Karakter 2010-2025.

Kemendiknas. (2011). Panduan Pelaksanaan Pendidikan Karakter. Kementrian Pendidikan Nasional.

Lickona, T. (1991). Educating for Character: How Our School Can Teach Respect and Responsibility. Bantam Books.

Lickona, T. (2012). Mendidik Untuk Membentuk Karakter: Bagaimana Sekolah dapat Memberikan Pendidikan Sikap Hormat dan Bertanggung Jawab. Bumi Aksara.

Listyarti Retno. (2012). Pendidikan Karakter dalam metode aktif, inovatif, dan kreatif. Esensi - Erlanggar Group.

Megawangi, R. (2010). Pengembangan program pendidikan karakter di sekolah: pengalaman sekolah karakter. Jakarta: Indonesia Heritage Foundation (IHF).

Riduwan, D. (2017). Skala Pengukuran Variabel-Variabel Penelitian. Alfabeta.

Rohman, M. M., Setyowati, D. L., \& Wasino, W. (2012). Pendidikan karakter di pesantren darul falah kecamatan jekulo kabupaten kudus. Journal of Educational Social Studies, 1(2).

Sugiyono, P. D. (2017). Metode Penelitian Bisnis: Pendekatan Kuantitatif, Kualitatif, Kombinasi, dan R\&D. Penerbit CV. Alfabeta: Bandung.

Sukardi, H. M. (2003). Metodologi penelitian pendidikan: Kompetensi dan praktiknya. Jakarta: Bumi Aksara.

Suratman. (1999). Pembinaan Mental, Fisik dan Disiplin. LAN.

Trisnawati, A. E., Wahyono, H., \& Wardoyo, C. (2018). Pengembangan Desa Wisata dan Pemberdayaan Masyarakat Berbasis Potensi Lokal. Jurnal Pendidikan: Teori, Penelitian, Dan Pengembangan.

Widyahening, C. E. T. (2016). Poetry and Moral Education In Teaching Learning Literature. Prosiding ICTTE FKIP UNS 2015, Vol 1, No.

https://scholar.google.com/scholar?cluster=4849386723736064559\&hl=en\&oi=scholarr

Wiyani Novan Ardy. (2012). Manajemen pendidikan karakter. Pedagogia.

Zubaedi. (2012). Desain Pendidikan Karakter. Kencana Prenada Media Group. 